\title{
Jan Dudziak
}

\section{Odpowiedzi Papieskiej Rady ds. Interpretacji Tekstów Prawnych w przedmiocie małżeństwa}

Ius Matrimoniale 1 (67), 153-168

1996

Artykuł został zdigitalizowany i opracowany do udostępnienia w internecie przez Muzeum Historii Polski w ramach prac podejmowanych na rzecz zapewnienia otwartego, powszechnego i trwałego dostępu do polskiego dorobku naukowego i kulturalnego. Artykuł jest umieszczony w kolekcji cyfrowej bazhum.muzhp.pl, gromadzącej zawartość polskich czasopism humanistycznych i społecznych.

Tekst jest udostępniony do wykorzystania w ramach dozwolonego użytku. 


\section{Ks. Jan Dudziak}

\section{Odpowiedzi Papieskiej Rady ds. Interpretacji Tekstów Prawnych w przedmiocie małżeństwa}

\section{Wprowadzenie}

Zanim przejdziemy do przedstawienia samego zagadnienia określonego tematem referatu, zapoznajmy się z kilkoma informacjami na temat samej „Rady ds. Interrpetacji Tektów Prawnych”. Ma ona bowiem już swoją bogatą historię.

Otóż, w kilka tygodni po wejściu w życie nowego Kodeksu Prawa Kanonicznego, tj. dnia 2 stycznia 1984 r. pap. Jan Pawel II, swoim motu proprio „Recognito iuris canonici codice”, śladem swojego poprzednika (pap. Benedykta XV), powołał do istnienia nowy organ dla autentycznej interpretacji Kodeksu Prawa Kanonicznego („Pontificia Commissio ad Codicem Iuris Canonici Authentice Interpretandum")'. Komisja zajęła miejsce poprzedniej, takiej samej Komisji, z $1917 \mathrm{r}^{2}$ i rozpoczęła niezwłocznie swoją działalność. Jednakże w kilka lat później przeszła ona swoją wewnętrzną reorganizację. Mianowicie w konstytucji apostolskiej „Pastor Bonus", z 28 czerwca 1988 r. została zmieniona nazwa Komisji oraz poszerzone kompetencje. W miejsce poprzedniej nazwy ten papieski organ interpretacyjny otrzymał następująca: „Pontificium Consilium de Legum Textibus Interpretandis” („Papieska Rada ds. Interpretacji Tekstów Prawnych"). ${ }^{3}$ Jak więc sama nazwa wskazuje, przedmiot działania Rady obejmuje wszelkie ustawy kościelne. Papieskiej Radzie Interpretacyjnej

\footnotetext{
' Communicationes (będę używał skrótu: Comm.), 15-1 (1984) 3-4.

2 "Cum iuris canonici”, motproptio pap. Benedykta XV, z 15 września 1917 r. W: Codex iuris canonici (1917), Typis Polyglottis 1947, s. L (=50), dokumenty wstępne.

'Comm., 20-1 (1988) 3-61. O Papieskiej Radzie dla Interpretacji Tekstów Prawnych Konstytucja mówi w artykułach: 154-158 swoich Norm, określających poszczególne dykasterie Kurii Rzymskiej. Tamże, s. 52-53.
} 
zostało też dnia 27 lutego 1991 r. poddane autentyczne wyjaśnianie Kodeksu Kanonów Kościołów Wschodnich.

Należy z naciskiem podkreślić, że zarówno wcześniejsza Papieska Komisja Interpretacyjna (do 1988 r.) jak i późniejsza Papieska Rada ds. Interpretacji Tekstów Prawnych (od 1989 r.) wspólpracują ściśle $z$ innymi dykasteriami Kurii Rzymskiej, bądź to wyjaśniając przedłożone sobie przez nie ustawy, bądź téz $w$ ogóle odsyłając im do ustalenia wykładnię norm leżących w zakresie ich kompetencyjnych działań. ${ }^{2}$ Stąd też trzeba uznać, że Papieska Rada ds. Interpretacji Tekstów Prawnych, acz jest urzędowym organem powszechnym dla stosowania wykładni prawa kościelnego, to nie jest organem jedynym. Wykladnię tę ustalają także w zakresie swoich działań specjalistycznych inne dykasterie kurialne. $\mathrm{Na}$ szczególne podkreślenie $w$ dziedzinie prawa małżeńskiego, zwłaszcza formalnego, zasługuja tu orzeczenia, deklaracje, odpowiedzi Najwyższego Trybunału Sygnatury Apostolskiej.

Przystępując obecnie do zasadniczego tematu, tj. do omówienia odpowiedzi Papieskiej Rady ds. Interpretacji Tekstów Prawnych, pragne poczynić trzy założenia. Po pierwsze, zgodnie z prawdą historyczna, autentyczne thumaczenia kanonów kodeksowych od 1984 do 1989 r. będę odnosił do Papieskiej Komisji dla Autentycznej Interpretacji Kodeksu Prawa Kanonicznego, ponieważ tak się wówczas nazywał ten organ Stolicy Apostolskiej. Wyjaśnienia zaś od roku 1990 będę już odnosił do przekształconej Komisji w Papieską Radę ds. Interpretacji Tekstów Prawnych. Tak więc obydwie nazwy będą tu musiały być stosowane, w zależności od czasu podejmowanych przez te organa działań. Po drugie, przedstawię także w artykule wypowiedzi na temat małżeńskich norm kodeksowych Najwyższego Trybunału Sygnatury Apostolskiej. Mają one formę deklaracji, dekretów, lub odpowiedzi i wnoszą wiążącą wykładnię odnośnych kanonów kodeksowych, zwłaszcza w zakresie małżeńskiego prawa procesowego. Chociaż współdziałanie Papieskiej Komisji czy późniejszej Rady dla Interpretacji Tekstów Prawnych nie występuje w tych decyzjach Sygnatury w sposób formalny, to jednak należy przyjać, że

\footnotetext{
1 Tamże, 23-1 (1991) 14-15.

${ }^{2}$ Tę współpracę Papieskiej Rady dla Interpretacji Tekstów Prawnych podkreśla dobitnie konstytucja „Pastor Bonus” z 1988 r. w artykule 156. Tamże, 20-1 (1988) 53. Por. J. K ruk ow s k i, Kompetencje Papieskiej Rady do Spraw Interpretacji Tekstów Prawnych. W: Analecta Cracoviensia, XXVI (1994) 549-552.
} 
decyzje te są owocem wzajemnych konsultacji oraz faktycznych uzgodnień. Stąd zasługują one na ich uwzględnienie. Oprócz Sygnatury Apostolskiej pojawi się jeden raz $w$ referacie także interwencja $w$ małżeńskie ustawy kodeksowe innej dykasterii Kurii Rzymskiej, a mianowicie Papieskiego Sekretariatu Stanu. Trzecim wreszcie założeniem jest propozycja, ażeby wyjaśnienia do ustaw kodeksowych przedstawić tutaj według kryterium kolejnej liczby kanonów w Kodeksie. Określenia tematyczne zawartych w kanonach wyjaśnień są własnymi sformułowaniami autora.

\section{Konsekwencje proceduralne zasady: ,matrimonium gaudet favore iuris" (KPK, kan. 1060).}

W kanonie 1060 nowy Kodeks Prawa Kanonicznego przejmuje bez zmian dotychczasową normę, która orzeka: „Małżenstwo cieszy się przychylnością prawa, dlatego w watpliwości należy je uważać za ważne, dopóki nie udowodni się czegoś przeciwnego".'

Przytoczony kanon nie wzbudził dotąd żadnej wątpliwości z punktu widzenia materialno-merytorycznego. Jednakże niektóre trybunały kościelne zaczęły po ukazaniu się Kodeksu naruszać tę normę z punktu widzenia proceduralno-formalnego. Albo czyniły to nieświadomie, albo też interpretowały zbyt szeroko, w sposób niedopuszczalny, zasadę „matrimonium gaudet favore iuris”, w odniesieniu do małżeństw zawieranych sukcesywnie. Sprawą zainteresował się Najwyższy Trybunał Sygnatury Apostolskiej, w wyniku otrzymywanych skarg i zażaleń na wymienione trybunały. Trybunały te nie są zresztą wymienione $\mathrm{z}$ nazwy $\mathrm{w}$ dokumentach Stolicy Apostolskiej.

Otóż Sygnatura Apostolska wydała w tej materii odpowiedni dokument pt. „Declaratio de recto modo procedendi in declaranda nullitate matrimoniorum successive initorum". Deklaracja nosi datę 18 czerwca 1987 r. i została podpisana przez najwyższe Czynniki tej dykasterii, tj. przez Kardynała Prefekta Aurelio Sabattani oraz przez Sekretarza Abpa Zenona Grocholewskiego.

' CIC (1917), can. 1114; P.M. Coronata, Institutiones iuris canonici, vol. III: De matrimonio, Marietti 1947, s. 27, n. 23; por. KPK (1983), kan. 1150; T. P a w l u k, Prawo małżeńskie. Olsztyn 1984 , s. $72 \cdot 73$. 
Jaki jest status qwaestionis deklaracji? Otóż, idzie w niej o właściwe prowadzenie spraw przez trybunały kościelne $w$ procesach o nieważność małżeństwa, gdzie związek małżeński zawierała kilkakrotnie sukcesywnie ta sama osoba. Gdy np. strona akatolicka domaga się orzeczenia nieważności swego małżeństwa, które zawierała po dwakroć lub po trzykroć i otrzymała już rozwód cywilny. Obecnie zaś pragnie zawrzeć dalsze małżeństwo ze stroną katolicką $i$ w tym celu domaga się od trybunału kościelnego orzeczenia nieważności swego poprzedniego związu, w sytuacji, gdy jej kompartnerzy żyja.

Postawiwszy $w$ ten sposób zagadnienie, Sygnatura Apostolska wykazuje najpierw niewłaściwa droge $w$ tej dziedzinie, jaka obieraja niektóre trybunały kościelne. Mianowicie zakładają one z góry na mocy kan. 1060 KPK („matrimonium gaudet favore iuris”), że pierwsze z tych sukcesywnie zawieranych małżeństw było ważne, a zatem automatycznie uważają każde następne, sukcesywnie zawierane, za nieważne, z tytułu „przeszkody węzła” w połączeniu z normą: „matrimonium gaudet favore iuris". W wyniku czego uznają daną osobę za wolną i zdatną do zawarcia nowego związku małżeńskiego. Trybunały te posługują się nawet skomplikowaną argumentacją, że istnieje jakoby przeszkoda zrywająca ,Z prawa kościelnego", wynikająca z samego faktu zewnętrznej celebracji małżeństwa (jeśli zewnętrznie nastapił fakt zawarcia związku małżeńskiego, to już jakoby tym samym istnieje ,impedimentum ecclesiasticum" do ponownego zawierania tegoż związku), bez względu na fakt jego ważności lub nieważności. Niektóre trybunały kościelne, opierając się na takim założeniu, zakładają z góry, że poraz pierwszy zawarte małżeństwo było de facto ważne i każde następne uznają za nieważne, ze wszystkimi skutkami prawnymi, stąd też danym osobom przyznają prawo do ponownego zawarcia małżeństwa.

Najwyższy Trybunał Sygnatury Apostolskiej ocenia jednoznacznie taki sposób postępowania za niedopuszczalny. W procedurze bowiem kościelnej należy dociekać faktów, a nie tworzyć założenia. Założenia, domniemania tworzy ustawodawca, na płaszczyźnie legislacyjnej, dla ochrony odpowiednich wartości. Natomiast sędzia ma obowiązek zweryfikować owe domniemania prawne, czy mianowicie w konkretnym przypadku zaistniał domniemywany przez ustawodawcę fakt. Według bowiem powszechnie przyjętych norm prawa: ,praesumptio cedit veritati", obowiązkiem sędziego jest więc w każdym przypadku zbadać „,veritatem 
facti". Ponadto należy zaprzeczyć przyjmowanej przez niektóre trybunały istnieniu czysto kościelnej przeszkody zrywającej węzła małżeńskiego o niedopuszczalności zawierania następnego małżeństwa, gdy zostało zawarte poprzednie.

Opierając się na powyższych przesłankach, teoretyczno - prawnych, Sygnatura Apostolska w swej deklaracji z 18 czerwca 1987 r., formułuje następujące zasady praktyczne:

1. Należy kategorycznie odrzucić (,prorsus reprobatur") praktykę tych trybunałów, które stosują przedstawioną powyżej procedurę.

2. Jeżeli ktoś oskarża o nieważność kilka sukcesywnie zawieranych małżeństw, to należy zastosować następujący sposób postępowania:

a. Przede wszystkim musi być rozpoznana sprawa nieważności pierwszego chronologicznie małżeństwa;

b. Po ewentualnym orzeczeniu jego nieważności, należy domniemywać, że następne małżeństwo sukcesywnie zawarte było ważne, a jego ewentualną nieważność należy dopiero udowodnić.

c. Tak należy podchodzić do każdego następnego związku małżeńskiego, zawieranego sukcesywnie.

3. Gdyby jakiś trybunał zastosował inny sposób postępowania w orzekaniu kolejno zawieranych małżeństw, byłoby to nadużyciem przeciwko dobru publicznemu Kościoła i o tym nadużyciu istnieje obowiązek powiadomienia Rzecznika Sprawiedliwości. Ten zaś z kolei jest zobowiązany podważyć tego rodzaju wyroki w sprawie kolejnych małżeństw, a także nowe małżeństwo, zawarte na podstawie takich decyzji wyrokowych. Obowiązek powiadomienia Rzecznika Sprawiedliwości spoczywa w tym wypadku przede wszystkim na Obrońcy Węzła tego trybunału, który orzekł nieważność pierwszego małżeństwa, ale także na każdej osobie, która zdobyła wiadomość o takim wyroku.

Wydając powyższą deklarację, Sygnatura Apostolska uzasadnia swoją kompetencję $w$ tej materii powinnością czuwania nad właściwym wymiarem sprawiedliwości w Kościele, nałożona jej przez Kodeks Prawa Kanonicznego. ${ }^{2}$

' Supremum Signaturae Apostolicae Tribunal. Prot. N. 14498/82 V.T. W: Comm., 19-1 (1987) 16-18.

${ }^{2}$ KPK (1983) kan. $1445 \S 3,1$; E. S z t a f to ow s k i, Podręcznik prawa kanonicznego, 4, Warszawa ATK 1986, s. 375. 


\section{Stosowalność kanonu o przymusie i bojaźni do małžeństw niekatolików ( KPK, kan. 1103).}

Kolejnym wyjaśnieniem, tym razem Papieskiej Komisji Interpretacyjnej, jest stwierdzenie, że kan. $1103 \mathrm{KPK}$ należy odnosić także do akatolików. Kanon ten brzmi następująco: „Nieważne jest małżeństwo zawarte pod przymusem lub pod wpływem ciężkiej bojaźni z zewnątrz, choćby nieumyślnie wywołanej, od której aby się uwolnić, zmuszony jest ktoś wybrać małżeństwo".' Sama odpowiedź Papieskiej Komisji jest zrozumiała, ponieważ przymus, brak wolności - są brakiem konsensu małżeńskiego, opartym na prawie naturalnym, a zatem norma kanonu 1103 KPK jest po prostu interpretacją boskiego prawa naturalnego. Może tu wszakże budzić pewne zaniepokojenie potencjalny, nie zaś imperatywny tryb odpowiedzi. Wydaje się, że jest to jednak watpliwość czysto akademicka, ponieważ styl odpowiedzi Komisji jest taki, że stosuje ona ściśle jej formę do formy zapytania. Zapytanie brzmiało: „Utrum vitium consensus de quo in can. 1103 matrimonio non catholicorum applicari possit", a więc nie ,applicari debeat". Stąd forma odpowiedzi zabrzmiała: „affirmative”, tzn. „applicari possit”. Nie ulega wszakże watpliwości, że odpowiedź należy rozumieć także w sensie imperatywnym. A zatem, gdyby się znalazła $w$ jakimś trybunale sprawa małżeństwa mieszanego, w którym strona akatolicka została przymuszona do zawarcia małżeństwa, trybunał miałby obowiazzek, a nie tylko fakultatywną możliwość, zastosowania kanonu $1103 \mathrm{KPK}$ o braku zgody z tytułu przymusu. Odpowiedź Komisji nosi datę 25 listopada $1986 \mathrm{r}^{2}$

\section{Sprostowanie blędu drukarskiego w Kodeksie odnośnie do kanonicznej formy małżeńskiej (KPK, kan. 1108 §).}

Do kan. 1108 \& 1, formułującego kanoniczna formę zawarcia małżeństwa, zakradł się błąd drukarski, który został autentycznie sprostowany przez samego Ojca świętego, na wniosek Komisji

KPK, kan. 1103; W. G ó r a l s k i, Kanoniczna zgoda małżeńska, Gdańsk „LEX” 1991, s. $211-242$.

2 Comm., 19-1 (1987) 149. 
Interpretacyjnej. Korekta ta została opublikowana w Acta Apostolicae Sedis przez Sekretariat Stanu z datą 21 listopada 1988 r. Błąd dotyczył cytowanego kanonu kontekstowego o stosowalności kanonicznej formy przy małżeństwach mieszanych. Otóż w pierwotnej wersji kan. $1108 \S 1$ widniał tam kan. $1127 \$ \$ 2-3$, podczas gdy powinno być, po sprostowaniu: kan. $1127 \S \S 1-2$. Wydanie polskiego tłumaczenia Kodeksu z 1984 r. błąd ten właśnie zawiera i jeśli ktoś się nim posługuje, winien nanieść tę poprawkę.'

\section{Określenie właściwości trybunałów w sprawach o nieważność małżeństwa (KPK, kan. 1673, 1-4).}

Kanon 1673, 1 - 4 ustala właściwość trybunałów kościelnych w tych sprawach o nieważność małżeństwa, które nie sa zarezerwowane Stolicy Apostolskiej, według kan. 1405. Notabene, według kan. 1405 KPK, określającego całokształt spraw zarezerwowanych sądownictwu Stolicy Apostolskiej, kompetencji Biskupa Rzymskiego podlegaja sprawy małżeńskie osób sprawujących najwyższą władzę państwową oraz te sprawy, które Papież wezwał przed swój trybunał. ${ }^{2}$ Inne sprawy małżeńskie podlegają czterem alternatywnym trybunałom, według ustaleń z kan. $1673 .^{3}$

Do tego kluczowego kanonu w zakresie prawa procesowego, istnieje kilka doniosłych wyjaśnień autentycznych. Po pierwsze, wpłynęło zapytanie do Papieskiej Komisji Interpretacyjnej natury ogólniejszej: czy mianowicie, wyrok trybunału, który orzekł ważność małżeństwa $w$ pierwszej instancji (,sententia negativa"), można poddać ponownemu rozpoznaniu w pierwszej instancji innemu trybunałowi, który jest kompetentny mocą kan. 1673?

\footnotetext{
' AAS, 80 (1988) 1819; W. G ó ral s k i, Kościelne prawo małżeńskie, Płock 1987, s. 78.

${ }^{2} \mathrm{KPK}$, kan. $1405 \S 1,1,4$; K. L ü d i c k e, Münsterischer Kommentar zum Codex luris Canonici, herausg. v. K. Lüdicke....O. Stoffel, Ludgerus Verlag, 1991, Prozesrecht, K. Lüdicke, Zuständigkeit, Kan. 1405.

${ }^{3}$ P. L o m b a r d i a - J.I. A r r i e t a, Codice di diritto canonico. Edizione bilingue commentata, vol. III, Roma, Edizioni Logos 1986, s. 1206-1207.
} 
Komisja Interpretacyjna uznała to zapytanie za problem o charakterze ogólniejszym na płaszczyźnie prawa procesowego i przekazała go do rozstrzygnięcia Najwyższemu Trybunałowi Sygnatury Apostolskiej. Po dokładniejszym zbadaniu zagadnienia, Sygnatura wydała $w$ tej sprawie, dnia 3 czerwca 1989 r., specjalny dokument zatytułowany: „Declaratio de foro competenti in casu nullitatis matrimonii post sententiam negativam in prima instantia latam” („Deklaracja o forum kompetentnym w sprawie o nieważność małżeństwa po negatywnym wyroku w pierwszej instancji"). Deklaracja składa się z kilku elementów i posiada moc wiążąca dla interpretacji kan. 1673 o właściwości trybunałów pierwszej instancji w zakresie spraw małżeńskich. Tak więc po myśli deklaracji:

1. Ta sama sprawa o nieważność małżeństwa, w której wydano stanowczy wyrok (,sententiam definitivam”), niezależnie od tego czy za ważnością czy za nieważnością nie może być ponownie rozpoznawana w tej samej instancji, chyba, że wchodzi w grę skarga o nieważność wyroku ("quaerela nullitatis").

2. Jeśliby taką sprawę jakiś trybunał pomimo wszystko de facto podjał, to:

a) jego niewłaściwość pozostaje absolutna;

b) jako taką zaś powinni ja podważyć wszyscy zainteresowani oraz jako taką powinien ja orzec $z$ urzędu sędzia;

c) nowy zaś wyrok wydany w takiej sprawie należy uznać za dotknięty wadą nieważności nieusuwalnej, którego nigdy nie można przekazać do wykonania.

3. Rozpoznanie merytorycznego faktu tego rodzaju sprawy nieważności małżeństwa, zarówno na szczeblu apelacji jak i odnośnie ponownego jej wszczęcia, należy wyłącznie do trybunału apelacyjnego tego sądu, który ją rozstrzygnął w pierwszej instancji.'

Sygnatura Apostolska umotywowała swoje wyjaśnienie bardzo szeroko, opierając się na ogólnych oraz szczegółowych przepisach kościelnego procesu o właściwości sądowej, a także na zasadzie prawa naturalnego: ,ne bis in idem", tzn., że byłoby przeciwko zdrowemu rozsądkowi, gdyby po raz drugi osądzal tę samą sprawę ten sam trybunat. ${ }^{2}$

\footnotetext{
'AAS, 81 (1989) 988-990; Comm., 21-2 (1989) II 7-I 18.

${ }^{2}$ Kontekstowymi oraz paralelnymi kanonami, na które się tu Sygnatura Apostolska powołuje, sa: kan. 1438-1430, 1444, 1459, 1461, 1620, 1626, 1632, 1654; Comm., 21-2 (1989) 117-118.
} 


\section{Rozumienie wikariusza sądowego w kształtowaniu właściwości forum dla spraw małżeńskich (KPK, kan. 1673, 3).}

Drugim, bardziej szczegółowym zagadnieniem, związanym z kan. 1673, jest sprawa rozumienia „,wikariusza sądowego", który jest kompetentny do kształtowania się właściwości forum dla spraw małżeńskich. Otóż punkt 3 omawianego kan. 1673 stwierdza, że jednym $z$ właściwych trybunałów w sprawach o nieważność małżeństwa, jest ...,trybunał miejsca, w którym strona powodowa ma stałe zamieszkanie, jeżeli obydwie strony przebywaja na terytorium tej samej Konferencji Episkopatu, i wikariusz sądowy stałego zamieszkania strony pozwanej, po jej wysłuchaniu, wyraża na to zgodę". Zaistniała tu wątpliwość, czy tym wikariuszem sądowym, o którym tu mowa, może być także alternatywnie wikariusz sądowy trybunału międzydiecezjalnego, oczywiście strony pozwanej. Odpowiedź Komisji, zatwierdzona przez Papieża dnia 17 maja 1986 r., jest złożona, tj. wyrażająca się w formule: "affirmative ad primum et ad mentem". Konkretnie Komisja zanegowała tu kompetencję wikariusza sądowego trybunału międzydiecezjalnego, lecz wyjaśniła, że w przypadku, gdyby nie było do dyspozycji wikariusza sądowego diecezji stałego zamieszkania strony powodowej, wówczas wymagana jest zgoda biskupa diecezjalnego, który wchodzi w miejsce swego oficjała.' Dodajmy, że ów brak wikariusza sądowego w ,poszczególnym przypadku", może pochodzić np., albo z chwilowego wakansu tego urzędu, albo też z faktu, że dana diecezja nie posiada własnego trybunału lecz korzysta $z$ trybunału międzydiecezjalnego.

\section{Zagadnienie ,wysłuchania strony pozwanej” przez wikariusza sądowego przed ustaleniem kompetentnego trybunału (KPK, kan. 1673, 3).}

Z kanonem 1673, 3, zaistniała w ostatnich latach jeszcze jedna trudność. Mianowicie w niektórych trybunałach zaczęla się ucierać uproszczona praktyka, że wikariusz sądowy stałego miejsca strony pozwanej nie zasięgał

Comm., 18-2 (1986) 408. 
jej zdania przed udzieleniem zezwolenia na prowadzenie sprawy przez trybunał stałego miejsca zamieszkania strony powodowej, jak tego domaga się norma kodeksowa. Zagadnienie przedłożono do wyjaśnienia Papieskiej Radzie dla Interpretacji Tekstów Prawnych, która przekazała je z kolei Sygnaturze Apostolskiej. Ta ostatnia zaś po bliższym zbadaniu sprawy, jak również po konsultacji $\mathrm{z}$ Papieską Radą dla Interpretacji Tekstów Prawnych, wydała $w$ tej materii „Decretum generale”, którego moca orzekła, że powyższej praktyki nie można zaakceptować („admitti nequit”). Dopatrzono się więc $w$ tym sposobie działania naruszenia prawa strony pozwanej. Ojciec święty zatwierdził ten dekret dnia 6 maja $1993 \mathrm{r}$. $^{\prime}$

W uzasadnieniu powyższej decyzji, Sygnatura Apostolska przytoczyła obszerną motywację. Niekóre z tych argumentów są następujące:

- Przede wszystkim domaga się tego właściwe brzmienie słów kan. 1673, 3 (,propria verborum significatio”).

- Wysłuchanie strony pozwanej ma na celu zapoznanie się przez wikariusza sądowego z okolicznościami dla udzielenia zgody lub odmowy na trybunał strony powodowej, po myśli kan. $127 \S 3$ ).

- Potwierdzenie wysłuchania strony pozwanej znajduje się w punkcie 4 tegoż kanonu 1673, gdzie jest mowa o analogicznym wysłuchaniu przy ustalaniu kompetencji trybunału tzw. „większości dowodów”, o czym zresztą będzie jeszcze mowa poniżej.

- Wreszcie, odpowiada to tenorowi odpowiedzi Papieskiej Komisji Interpretacyjnej z dnia 28 lutego 1986 r., a zatwierdzonej przez Papieża 17 maja tegoż roku, która dotyczyła wprost ustalenia wikariusza sądowego, lecz ubocznie zakładała także wysłuchanie strony pozwanej przed udzieleniem zezwolenia na odnośny trybunał sprawy małżeńskiej. ${ }^{2} \mathrm{O}$ tym ostatnim wyjaśnieniu była mowa powyżej, w punkcie $V$ - tym niniejszego referatu.

\section{Kompetentne forum $\mathrm{z}$ racji na tzw. ,większość dowodów”} (KPK, kan. 1673, 4).

Do kan. 1673 istnieje jeszcze jedno ważne wyjaśnienie interpretacyjne. Dotyczy ono jego 4 - tego numeru, gdzie jest mowa o właściwości

' Tamze, 25-2(1993) 174-175.

2 T a m że. 
trybunału w sprawach małżeńskich ze względu na tzw. „większość dowodów" (,tribunal plerarumque probationum"). Kodeks mianowicie stwierdza, że właściwym jest ,trybunał, na terenie którego faktycznie trzeba będzie zbierać większość dowodów, jeżeli wyrazi na to zgodę wikariusz sądowy stałego zamieszkania strony pozwanej, który wcześniej powinien ją zapytać, czy nie zgłasza czegoś, co należałoby wyłączyć" (,num quid excipiendum habeat").

Na temat rozumienia tej normy Sygnatura Apostolska wydala, dnia 27 kwietnia 1989 r., obszerniejsze wyjaśnienie w formie tzw. „Declaratio de foro plararumque probationum" („Deklaracja na temat wlaściwości trybunału większości dowodów"). ${ }^{2}$ Okazją do wydania tej deklaracji było pismo pewnego wikariusza sądowego (nie ujawnionego $z$ nazwiska), skierowane do Sygnatury. Sygnatura Apostolska w reakcji na to pismo oraz w uzasadnieniu, że zgodnie z kan. 1445 \& 3, l powinna „czuwać nad prawidłowym wymiarem sprawiedliwości w Kościele", podaje wyczerpujące wyjaśnienia, związane $\mathrm{z}$ wyznaczaniem trybunału „większości dowodów".

1. Trybunał ,większości dowodów" z kan. 1673, 4, może być mianowicie tylko wówczas uważany za prawnie kompetentny, gdy zostaną dokładnie spełnione wymienione tu warunki. A więc, gdy wyrazi na to zgodę wikariusz sądowy stałego miejsca zamieszkania strony pozwanej, który wcześniej powinien ją zapytać, czy nie wytacza jakiegoś zarzutu, który należałoby uwzględnić (,num quid excipiendum habeat"). Przed spełnieniem tych warunków trybunał rzekomej ,większości dowodów” nie może ważnie podjąc żadnych aktów proceduralnych, jak np. wezwanie stron, podejmowanie ugody, itd. Ten brak kompetencji Sygnatura Apostolska motywuje kanonem 127 \& 2 KPK, który określa warunki ważności lub godziwości działania wszelkiego przełożonego kościelnego, gdy ustawa domaga się od niego zgody lub rady niektórych pojedynczych osób do podejmowania określonych aktów prawnych. ${ }^{3}$ Co więcej, to: wyrażenie zgody wikariusza sądowego stałego zamieszkania strony pozwanej na trybunał „większości dowodów” powinno być wyraźne, nie wystarczy domniemane, np. w przypadku braku odpowiedzi w wyznaczonym terminie. ${ }^{4}$

KPK, kan. 1673, 4; E. S z t a f row s k i, dz. cyt., s. 383.

2 AAS, 81 (1989) 892-894.

${ }^{3}$ T. P a w 1 u k, Prawo kanoniczne według Kodeksu Jana Pawła II. t. I: Zagadnienia wstępne i normy ogólne, Olsztyn 1985, s. 290.

+ Comm., $21-2$ (1989) 114. 
2. Samego trybunału „większości dowodów” nie można $\mathrm{z}$ zasady pojmować tylko pod kątem dostępności świadków strony powodowej. Należy także brać pod uwagę dostępność innych dowodów po stronie powodowej, a także dostępność dowodów zbieranych z urzędu. Owszem, za trybunał „większości dowodów" należy uważać nie trybunał dowodów potencjalnych, teoretycznie wziętych, lecz trybunał większości dowodów, które są faktycznie do zebrania. Przy czym należy się tu kierować nie tyle ilością dowodów, co raczej ich przydatnością motywacyjną. Nie może być z kolei pretekstem do wyboru trybunału "większości dowodów" okoliczność, że leży on na terenie własnego kraju, lecz kryterium określającym winna być zawsze faktyczna możliwość zebrania większości dowodów. Ponadto, nie należy się nigdy odcinać w takim wyborze od ważniejszych okoliczności okresu bezpośrednio przedślubnego oraz poślubnego, jako bardzo doniosłych w procesach małżeńskich. Dlatego też trudno byłoby przyjać za kompetentne forum trybunał innej diecezji, niż tej, w której się strony poznały, zawarly małżeństwo oraz żyły wspólnie przez wiele lat.'

3. Przy ustalaniu wikariusza sądowego miejsca zamieszkania strony pozwanej, należy mieć na uwadze odpowiedź Papieskiej Komisji Interpretacyjnej z $1986 \mathrm{r}$, dotyczącej tego samego kan. 1673, 3. Jest to bowiem ta sama terminologia. ${ }^{2}$ Odpowiedź ta została omówiona powyżej, w punkcie: $V I-$ tym.

4. Zgodnie $z$ wymogiem kan. $127 \S 3$, wszyscy zobowiazani do wyrażenia zgody na różne akty prawne, mają obowiązek wyrazić swoje zdanie „szczerze”, tj. zgodnie ze swoim sumieniem. W tym celu wikariusz sądowy stałego zamieszkania strony pozwanej, powinien rzetelnie zebrać wszystkie informacje na ten temat, łącznie $z$ zasięgnięciem opinii samej strony pozwanej, jej motywacji za udzieleniem zgody lub jej odmówieniem, itd. Działania te nie moga uchodzić za jakiś brak zaufania wobec proszącego o zgodę trybunału „większości dowodów”, lecz mają uchodzić za w pełni zasadne. ${ }^{3}$

5. Strona pozwana, która ma być pytana o zdanie przez wikariusza sądowego swego zamieszkania, ma pełne prawo być przy tym

\footnotetext{
1 T a mże, s. 115.

${ }^{2}$ T a m że.

${ }^{3}$ Ta $\mathrm{m} \dot{z} \mathrm{e}$.
} 
poinformowaną o takich sprawach, jak przedmiot zgłoszonego przedmiotu sporu, czyli o tytule procesu, o wysunietych dowodach, itd. '

W swoich motywacjach omawianej Deklaracji, Sygnatura Apostolska powołuje się nie tylko na ogólniejsze zasady prawa kanonicznego lecz także na normy moralne, zawarte zwłaszcza w przemówieniu Pap. Jana Pawła II do Pracowników Roty Rzymskiej, z dnia 26 stycznia 1989 r. Było to jedno $\mathrm{z}$ bardzo doniosłych przemówień o gwarancjach podstawowych praw osoby ludzkiej, pociaggających za sobą konieczność przyznania każdemu człowiekowi przez ustawy kościelne prawa do własnej obrony. ${ }^{2}$

\section{Podmiotowość procesowa akatolików a "duplex sententia conformis" w sprawach małżeńskich (KPK, kan. $1684 \S \S 1-2$ ).}

Kan. $1684 \quad \S \S 1-2$ KPK zawiera znaną nam normę o konieczności osiagnięcia w procesie małżeńskim podwójnego wyroku za nieważnościa małżeństwa, dla osiagnięcia stanu wolnego przez strony i dla możliwości ponownego zawarcia małżeństwa. Drugi wyrok, w instancji apelacyjnej, może być także wydany w formie dekretu. Idzie tylko o to, ażeby ten drugi wyrok nie zawierał zakazu wstępowania w ponowne zwiazzki małżeńskie, lub by takiego zakazu nie wydał oddzielnie Ordynariusz miejsca. ${ }^{3}$

W związku z tą normą zostało przedłożone Najwyższemu Trybunałowi Sygnatury Apostolskiej następujące pytanie: w założeniu, że akatolicy, według 11 kan. KPK, nie podlegaja ustawom czysto kościelnym, a wymóg kan. 1684 o konieczności podwójnego wyroku za nieważnością małżeństwa dla zawarcia nowego związku małżeńskiego jest ustawą czysto kościelną, czy godzi się asystować przy małżeństwie strony katolickiej z akatolicka,

1 T a mże, s. 116.

${ }^{2}$ L.' Osservatore Romano, 27.01.1989, s. 4.

${ }^{3}$ „Po tym, gdy wyrok stwierdzajacy za pierwszym razem nieważność małżeństwa zostanie potwierdzony w trybunale apelacyjnym czy to dekretem, czy drugim wyrokiem, ci, których małżeństwo zostało orzeczone za nieważne, mogą zawrzeć nowe małżeństwo zaraz, gdy dekret lub drugi wyrok zostanie im podany do wiadomości, chyba że zostało to zabronione zakazem zamieszczonym w wyroku lub dekrecie albo przez ordynariusza miejsca. Przepisy kan. 1644 należy zachować również, jeżeli wyrok, który orzekł nieważność małżeństwa, został potwierdzony nie drugim wyrokiem, lecz dekretem." KPK, kan.1684 $\S \S 1-2 ;$ P. Lo mbardia - J.I. Arrieta, dz. eyt., s. 1217. 
zważywszy, że poprzednie małżeństwo tej ostatniej (strony akatolickiej) ze stroną również akatolicką zostało orzeczone jako nieważne przez trybunał kościelny, ale tylko w pierwszej instancji?

Odpowiedź Sygnatury Apostolskiej w formie „Responsio”, z dnia 1 lutego 1990 r., brzmi przecząco, przy równoczesnym podkreśleniu obowiązku bezwzględnego przestrzegania kanonów: 1682, 1684, 1686 1688, które się domagają podwójnego wyroku jednobrzmiącego, dla moźliwości asystowania przy ponownym małżeństwie strony katolickiej, nawet ze stroną niekatolicką.

Co do tej strony akatolickiej, odpowiedź Sygnatury jest zaopatrzona bardzo wnikliwa motywacją prawna. Najważniejszymi elementami tej motywacji są trzy argumenty.

Po pierwsze, że strona akatolicka, ubiegająca się w Kościele katolickim o zawarcie małżeństwa ze stroną katolicka, jest pośrednio także podległa prawu czysto kościelnemu, a to mocą kan. 1059, który stwierdza: „Małżeństwo katolickie, chociażby tylko jedna strona była katolicka, podlega nie tylko prawu Bożemu, lecz także kanonicznemu".'

Po drugie, norma kan. $1085 \$ 2^{2}$, która jest komplementarna do kan. 1684, chociaż jest sama w sobie prawem czysto kanonicznym, to jednak zabezpiecza nie tylko czysto kościelne prawo. ${ }^{3}$ Chodzi tu przede wszystkim o ochronę prawa Bożego o nierozerwalności węzła małżeńskiego.

Po trzecie, także strona akatolicka cieszy się w świetle procesowego prawa kanonicznego zdolnością zaskarżenia ważności małżeństwa w sądzie kościelnym. A zatem podlega ona temu ustawodawstwu. ${ }^{4}$

W odpowiedzi tej zostala w pełni potwierdzona zdolność podmiotowa strony akatolickiej „standi in iudicio” w sprawach o niewaźność małżeństwa oraz obowiązywalność akatolików do przestrzegania w takich przypadkach kanonicznego prawa procesowego.

'P. Lombardia - J.I. A rrieta, dz. cyt., vol. H1, s. 751.

${ }^{2}$ "Chociaż pierwsze małżeństwo było nieważnie zawarte lub zostało rozwiązane $z$ jakiejkolwiek przyczyny, nie wolno dlatego zawrzeć ponownego małżeństwa, dopóki nie stwierdzi się, zgodnie z prawem i w sposób pewny, nieważności lub rozwiązania pierwszego." KPK, kan. $1085 \$ 2$.

"T $\mathrm{T}$ am ż e.

${ }^{4}$ Comm., 24-2 (1992) 201-202. 


\section{Proces malżeński oparty na dokumentach a badanie stanu wolnego narzeczonych (KPK, kan. 1686).}

Kan. 1686 określa warunki przeprowadzenia tzw. procesu małżeńskiego opartego na dokumentach.' $W$ związku z tą normą przedstawiono Papieskiej Komisji Interpretacyjnej zapytanie, dotyczące przedmałżeńskiego badania stanu wolnego narzeczonych. Mianowicie, czy jest konieczne przeprowadzenie procesu opartego na dokumentach, o którym mowa w przytoczonym kanonie (1686), dla stwierdzenia stanu wolnego takich narzeczonych, którzy będąc zobowiązani do formy kanonicznej, zawarli tylko małżeństwo cywilne, lub przed szafarzem akatolickim. Odpowiedź Komisji jest przecząca, tzn. nie jest konieczne w takim przypadku prowadzenie procesu opartego na dokumentach, po myśli kan. 1686 , lecz wystarczy przeprowadzenie zwykłych dochodzeń przedmałżeńskich, po myśli kan. $1066-1067 .^{2}$ Odpowiedź tę zatwierdził pap. Jan Pawel II w dniu 11 lipca $1984 \mathrm{r}^{3}$

\section{Zakończenie.}

W podsumowaniu pragnę jeszcze raz krótko i syntetycznie ując przedstawione zagadnienia z zakresu kodeksowego prawa małżeńskiego, które zostały bliżej naświetlone oraz autentycznie zinterpretowane, bądź to przez Papieską Komisję Interpretacyjna (od 1984 do 1989 r.), bądź przez Papieską Radę ds. Interpretacji Tekstów Prawnych, bądź też przez inne dykasterie Kurii Rzymskiej, zwłaszcza zaś przez Najwyższy Trybunał Sygnatury Apostolskiej. Zagadnieniami tymi są:

' „Po przyjęciu skargi przedstawionej zgodnie z przepisem kan. 1677 wikariusz sądowy lub sędzia przez niego wyznaczony, pomijając formalności zwyczajnego procesu, ale wzywając strony z udziałem obrońcy węzła, może orzec nieważność małżeństwa, jeśli z dokumentu, który nie podlega żadnemu sprzeciwowi lub zarzutowi, wynika w sposób pewny istnienie przeszkody zrywającej lub brak formy prawnej, jeżeli z taką samą pewnością wiadomo, że dyspensa nie została udzielona albo że pełnomocnik nie posiadał ważnego zlecenia." KPK, kan. 1686.

${ }^{2}$ J. D u d z i a k, Kanoniczne przygotowanie narzeczonych do małżeństwa. W: Tarnowskie Studia Teologiczne, XI (1992) $145 \mathrm{nn}$.

${ }^{3}$ AAS, 76 (746-747). 
- Konsekwencje proceduralne zasady: „matrimonium gaudet favore iuris" (kan. 1060);

- Stosowalność kodeksowej ustawy o przymusie i bojaźni do małżeństw akatolików (kan. 1103);

- Sprostowanie błędu drukarskiego odnośnie do kanonicznej formy małżeńskiej (kan. $1108 \S 1$ );

- Określenie właściwości trybunałów w sprawach o nieważność małżeństwa (kan. $1673 \S \S 1-2)$;

- Rozumienie wikariusza sądowego w kształtowaniu właściwego forum dla spraw małżeńskich (kan. 1673, 3);

- Zagadnienie „wysłuchania strony pozwanej” przez wikariusza sądowego przed ustaleniem kompetentnego trybunału (kan. 1673, 3);

- Kompetentne forum ze względu na tzw. „większość dowodów” (kan. $1673,4)$

- Podmiotowość procesowa akatolików a „duplex sententia conformis" w sprawach małżeńskich (kan. $1684 \S \S 1-2$ );

- Proces małżeński oparty na dokumentach a badanie stanu wolnego nupturientów (kan. 1686).

Tak przedstawia się dotychczasowy stan autentycznych wyjaśnień do norm małżeńskich zawartych w Kodeksie Prawa Kanonicznego z 1983 r. 